\title{
PENGARUH CURRENT RATIO (CR), RETURN ON EQUITY (ROE), DAN SALES GROWTH TERHADAP HARGA SAHAM YANG BERDAMPAK PADA KINERJA KEUANGAN PERUSAHAAN (Pada Perusahaan Manufaktur Sektor Makanan dan Minuman Yang terdaftar di Bursa Efek Indonesia)
}

\author{
Asep Muhammad Lutfi ${ }^{1)}$ \& Nardi Sunardi ${ }^{1)}$
}

1.2) dosen universitas pamulang, email : dosen01030@unpam.ac.id

ARTICLES
INFORMATION
JURNAL SEKURITAS
(Saham, Ekonomi, Keuangan
dan Investasi)
Vol.2, No.3, Mei 2019
Halaman : $83-100$
LPPM \& Prodi Manajemen
UNVERSITAS PAMULANG
ISSN (online) : 2581-2777
ISSN (print) : 2581-2696
Keyword:
Current Ratio, Return On
Equity, Sales Growth, Harga
Saham dan Kinerja
Keuangan

JEL. classification :

C33, G21, G24, N15, N25

\section{Contact Author:}

PRODI MANAJEMEN UNPAM

U.Surya Kencana No.1 Pamulang

Tangerang Selatan - Banten

Teb. 021$\} 7412508$. Fax $(021) 7412491$ Email:

umalinance urpam@gmail com
Penelitian ini bertujuan untuk mengetahui pengaruh rasio Current Ratio, Return On Equity, Sales Growth Terhadap Harga Saham Yang Berdampak pada kinere Keuangan Perusahaan pada perusahaan industri manufaktur Makanan dan Minuman yang tercatat di Bursa Efek Indonesia. Pengumpulan data dilakukan dengan pengambilan data primer berupa laporan keuangan 15 perusahaan periode 2012 - 2017 dimana laporan keuangan dibuat data panel dan diolah dengan software Eviews 9.0.

Metode analisis yang digunakan adalah analisis deksriptif. Analisis data meliputi uji kelayakan data, analisis regresi, serta pengujian hipotesis secara parsial dan simultan.

Hasil penelitian ini menunjukan bahwa (1) pengaruh Current Ratio terhadap harga saham (CR) negatif dan signifikan, (2) pengaruh Return On Equity terhadap harga saham positif dan signifikan, (3) pengaruh Sales Growth terhadap harga saham positif dan tidak signifikan, (4) pengaruh current ratio, return on equity dan sales growth terhadap harga saham secara simultan dengan prob 0,0000 dan F-Statistic 20,94081 positif dan signifikan (5) pengaruh harga saham terhadap kinerja keuangan positif dan signifikan.

This study aims to determine the effect of the Current Ratio ratio, Return On Equity, Sales Growth Against Stock Prices that have an impact on the Company's financial performance in Food and Beverage manufacturing industry companies listed on the Indonesia Stock Exchange. Data collection is done by taking primary data in the form of 15 companies financial statements for the period 2012 2017 where financial reports are made panel data and processed with Eviews 9.0 software.

The analytical method used is descriptive analysis. Data analysis includes data feasibility test, regression analysis, and hypothesis testing partially and simultaneously.

The results of this study indicate that (1) the effect of Current Ratio on stock prices (CR) is negative and significant, (2) the effect of Return on Equity on positive and significant stock prices, (3) the effect of Sales Growth on stock prices is positive and insignificant, ( 4) the effect of current ratio, return on equity and sales growth on stock prices simultaneously with prob 0.0000 and F-Statistics 20.94081 positive and significant (5) the effect of stock prices on positive and significant financial performance 


\section{A. Pendahuluan}

Arus globalisasi dan moderenisasi telah menyebabkan terjadinya integrasi pasar dunia, sehingga perekonomian suatu negara tidak dapat terhindar dari pengaruh perubahan ekonomi di belahan dunia lainnya. Arus barang dan arus modal telah melewati batas-batas negara dalarn waktu yang singkat. Pemilik modal memiliki banyak peluang dalam memilih sektor industri apa dan di negara mana investasi akan dipilih. Pemerintah berusaha menyediakan berbagai alternatif sumber dana yang dapat dimanfaatkan oleh perusahaan sesuai dengan kebutuhannya untuk mendorong perkembangan perusahaan.

Pemerintah Indonesia beranggapan bahwa pasar modal merupakan sarana yang dapat mendukung percepatan pembangunan ekonomi Indonesia. Husnan (2001:3) "Pasar modal merupakan pasar untuk berbagai instrumen keuangan atau sekuritas jangka panjang yang bisa diperjual belikan, baik dalam bentuk hutang ataupun modal sendiri, baik yang diterbitkan oleh pemerintah, public authorities, maupun perusahaan swasta" Pasar modal menggalang pergerakan dana jangka panjang dari masyarakat (investor) yang kemudian disalurkan pada sektor-sektor yang produktif dengan harapan sektor tersebut dapat berkembang dan menghasilkan lapangan perkerjaan yang baru bagi masyarakat.

Perusahaan makanan dan minuman merupakan salah satu kategori sektor industri di Bursa Efek Indonesia (BEI) yang mempunyai peluang untuk tumbuh dan berkembang. Industri makanan dan minuman diprediksi akan membaik kondisinya. Hal ini terlihat semakin menjamurnya industri makanan dan minuman di negara ini khususnya semenjak memasuki krisis berkepanjangan. Kondisi ini membuat persaingan semakin ketat sehingga para manajer perusahaan berlomba- lomba mencari investor untuk menginvestasikan dananya di perusahaan makanan dan minuman tersebut.

Barang konsumsi menjadi industri yang penting bagi perkembangan perekonomian bangsa. Hal ini tidak terlepas dari perusahaan-perusahaan yang bergerak dalam industri barang konsumsi di Indonesia. Tidak bisa dipungkiri bahwasanya dalam proses produksi barang konsumsi dibutuhkan banyak sumber daya termasuk di dalamnya sumber daya manusia. Industri barang konsumsi mempunyai peranan dalam menyerap tenaga kerja dan meningkatkan pendapatan pada suatu negara.

Rasio keuangan menjelaskan suatu hubungan antara suatu jumlah tertentu dengan jumlah yang lain dalam suatu laporan keuangan. Tujuan analisis rasio keuangan dimaksudkan agar perbandingan-perbandingan yang dilakukan terhadap pos-pos dalam laporan keuangan merupakan suatu perbandingan yang logis, dengan menggunakan ukuran-ukuran tertentu yang memang telah diakui mempunyai manfaat tertentu pula, sehingga hasil analisisnya layak dipakai sebagai pedoman pengambilan keputusan.

Analisis rasio keuangan merupakan dasar untuk menilai dan menganalisa prestasi operasi perusahaan. Analisis rasio keuangan juga dapat digunakan sebagai kerangka kerja perencanaan dan pengendalian keuangan. Menurut Moaljadi (2006:48) Analisis rasio keuangan biasanya dikelompokkan kedalam empat kelompok rasio yaitu : Rasio Likuiditas, Rasio Leverage, Rasio Aktivitas, Rasio Profitabilitas.

Menurut Moeljadi (2006:48) Rasio Likuiditas Istilah likuiditas menunjukkan kemampuan suatu perusahaan untuk memenuhi kewajiban-kewajiban keuangannya dalam jangka waktu pendek atau yang segera harus dibayar.Tingkat likuiditas yang tinggi menunjukkan bahwa perusahaan tidak mengalami kesulitan membayar kewajibannya dalam jangka waktu pendek, sehingga kreditur tidak perlu khawatir dalam memberikan pinjaman. Alat pemenuhan kewajiban keuangan jangka panjang ini berasal dari unsurunsur aktiva yang bersifat likuid, yakni aktiva lancar dengan perputaran < satu tahun, karena lebih mudah dicairkan daripada aktiva tetap yang perputarannya $>$ satu tahun.

Current Rasio merupakan jenis rasio Likuiditas yakni Rasio yang menggambarkan kemampuan suatu perusahaan untuk melunasi semua kewajiban yang harus segera 
dipenuhi (Hutang jangka pendeknya) yakni dengan cara membandingkan aktiva lancar dengan hutang lancer.

Menurut Bambang Riyanto (2001:26), "Current ratio merupakan ukuran yang berharga untuk mengukur kesanggupan suatu perusahaan untuk memenuhi current obligation - nya.

Menurut S. Munawir (2007:72), "Rasio lancar (Current ratio) yaitu perbandingan antara jumlah aktiva lancar dengan hutang lancar, rasio ini menunjukan bahwa nilai kekayaan lancar (yang segera dapat dijadikan uang) ada sekian kali hutang jangka pendek.

Menurut Agnes Sawir (2011:8), menerangkan bahwa Current ratio merupakan ukuran yang paling umum digunakan untuk mengetahui kesanggupan memenuhi kewajiban jangka pendek, karena rasio ini menunjukan seberapa jauh tuntutan dari kreditor jangka pendek dipenuhi oleh aktiva yang diperkirakan menjadi uang tunai dalam periode yang sama dengan jatuh tempo utang".

Jadi menurut pengertian di atas Current Ratio adalah rasio untuk mengukur kemampuan perusahaan dalam membayar kewajiban jangka pendek atau utang yang segera jatuh tempo dengan menggunakan aktiva lancar yang tersedia. Semakin tinggi Rasio berarti semakin terjamin hutang-hutang perusahaan bagi kreditur, Current Ratio menunjukkan kemampuan suatu perusahaan untuk memenuhi kewajiban-kewajiban keuangannya yang harus segera dibayar dengan menggunakan utang lancar. Rasio ini merupakan rasio untuk mengukur kemampuan perusahaan dalam membayar kewajiban jangka pendek atau utang yang segera jatuh tempo pada saat ditagih secara keseluruhan.

Menurut Hanafi (2013:42). Profitability ratio merupakan kemampuan perusahaan untuk mengukur keuntungan perusahaan pada tingkat penjualan, aset, dan modal saham tertentu. Ada tiga rasio profitabilitas yang sering digunakan yaitu : Net Profit Margin, Return On Asset, dan Return On Equity Penelitian ini akan menggunakan Return On Equity. mempunyai tujuan yaitu untuk mengahasilkan laba bersih pada perusahaan dan pemegang saham, agar harga saham perusahaan mendapatkan laba bersih yang maksimal. Selain itu, pada tahap pertumbuhan perusahaan harus mempunyai kesempatan tumbuh berkembang pada masa depan. Sehingga perusahaan agar dapat mempunyai pengaruh yang positif dan signifikan terhadap harga saham.

Return On Equity Merupakan salah satu rasio Profitabiloitas yaitu Rasio yang membandingkan laba bersih setelah pajak dengan ekuitas yang telah diinvestasikan pemegang saham perusahaan, Rasio ini menunjukan kemampuan perusahaan dalam menghasilkan laba bersih yang tersedia bagi pemilik atau investor ROE sangat bergantung pada besar kecilnya perusahaan, misalnya untuk perusahaan kecil tentu memiliki modal yang relative kecil, sehingga ROE yang dihasilkanpun kecil, begitu pula sebaliknya untuk perusahaan besar.

Hanafi (2008:42) Return on Equity mengukur kemampuan perusahaan menghasilkan laba bersih berdasarkan modal tertentu. Kenaikan rasio ini berarti terjadi kenaikan laba bersih dari perusahaan yang bersangkutan. Jadi, para investor dapat menggunakan indikator ROE sebagai bahan pertimbangan dalam memilih saham atau menanamkan modalnya, karena rasio ini menunjukkan bahwa dengan kinerja manajemen meningkat maka perusahaan dapat mengelola sumber dana pembiayaan operasional secara efektif untuk menghasilkan laba bersih sehingga saham perusahaan banyak diminati investor. Seperti rasio keuangan tradisional pada umumnya ROE tidak mempertimbangkan unsur resiko dan jumlah modal yang diinvestasikan karena ROE hanya melihat sisi laba dan jumlah saham yang beredar.

Sales Growth mencerminkan kemampuan perusahaan dari waktu ke waktu. Semakin tinggi tingkat pertumbuhan penjualan suatu perusahaan maka perusahaan tersebut berhasil menjalankan strateginya. " menurut Fahmi (2014:82) sales Growth adalah Rasio pertumbuhan yaitu rasio yang mengukur seberapa besar kemampuan perusahaan dalam mempertahankan posisinya di dalam industri dan dalam perkembangan ekonomi secara umum. Rasio pertumbuhan ini dilihat dari berbagai segi 
sales (penjualan), earning after tax (EAT), laba per lembar saham, dividen perlembar saham, dan harga pasar perlembar saham." Menurut kasmir (2012:107) Rasio Pertumbuhan penjualan menunjukan sejauh mana perusahaan dapat meningkatkan penjualannya dibandingkan dengan total penjualan secara keseluruhan. Perubahan Kenaikan atau penurunan aktiva perusahaan yang meyakini bahwa presentase perubahan total aktiva merupakan indicator yang lebih baik dalam mengukur Sales Growth.

Seperti karakteristik saham yang diuraikan di atas, harga saham akan mengalami penurunan dan peningkatan yang drastis atau fluktuasi. Harga saham yang fluktuatif menunjukan adanya permintaan atau perkembangan industry yang fluktuatif juga. Perkembangan atau perubahan harga saham industri Makanan dan Minuman yang ada di Indonesia dapat dilihat pada gambar berikut:

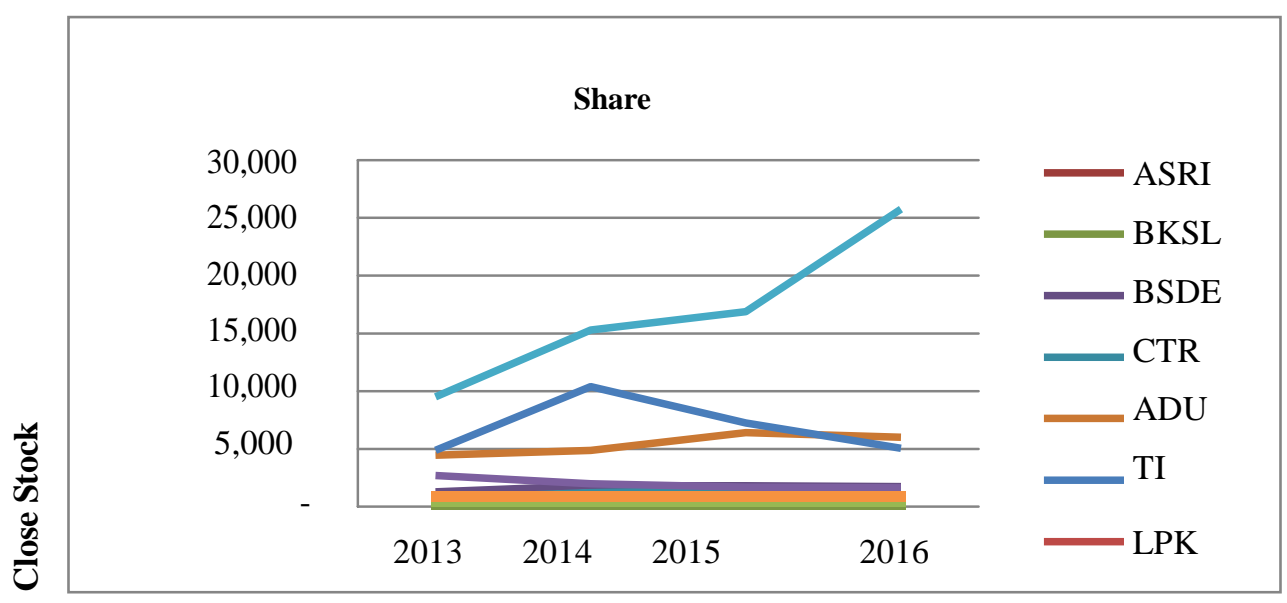

Gambar 1.1

Perkembangan Harga Saham

Sumber : data Sekunder dari BEI diolah

Dari gambar 1.1 di atas dapat dilihat bahwa dari 10 perusahaan Makanan dan Minuman yang ada di Indonesia, 90\% dari grafik menunjukan penurunan dari tahun 2013 samapai dengan 2016.

Tabel 1.3

\section{Rata-rata Harga saham Perusahaan Manufaktur Makanan dan Minuman yang} terdaftar di BEI

\begin{tabular}{|c|c|}
\hline Tahun & Rata-Rata Harga Perlembar Saham \\
\hline 2012 & 2.296 \\
\hline 2013 & 3.136 \\
\hline 2014 & 3.369 \\
\hline 2015 & 2.704 \\
\hline 2016 & 3.384 \\
\hline 2017 & 3.257 \\
\hline
\end{tabular}

Sumber: data sekunder dari BEI (diolah)

Dari Tabel 1.3 di atas dapat dilihat bahwa dari 10 perusahaan Makanan dan Minuman yang ada di Indonesia, menunjukan harga saham mengalami Fluktuasi. Harga saham mengalami kenaikan dari tahun 2013 dan 2014 akan tetapi di tahun 2015 
mengalami penurunan.

Nilai perusahaan akan tercermin dalam nilai pasar sahamnya. Semakin tinggi harga saham semakin tinggi pula nilai perusahaan bagi perusahaan yang sudah go public karena nilai perusahaan dapat menunjukkan nilai aset yang dimiliki perusahaan seperti surat-surat berharga. Saham merupakan salah satu surat berharga yang dikeluarkan oleh perusahaan. Tinggi rendahnya harga saham banyak dipengaruhi oleh kondisi emiten. Salah satu faktor yang mempengaruhi harga saham adalah kemampuan perusahaan membayar dividen. Apabila dividen yang dibayar tinggi, harga saham cenderung tinggi sehingga nilai perusahaan juga tinggi. Sebaliknya bila dividen yang dibayarkan kecil maka harga saham perusahaan tersebut rendah sehingga nilai perusahaan rendah. Kemampuan membayar dividen erat hubungannya dengan kemampuan perusahaan memperoleh laba. Tinggi rendahnya harga saham ini juga merupakan refleksi dari keputusan investasi.

Perusahaan harus dalam keadaan yang menguntungkan atau memiliki tingkat profitabilitas yang tinggi. Hal ini dikarenakan dengan tingkat profitabilitas yang tinggi, perusahaan dapat mempertahankan kelangsungan hidupnya. Selain itu, tanpa adanya keuntungan akan sangat sulit bagi perusahaan untuk melakukanpendanaan internal maupun eksternal. Perusahaan harus meningkatkan profitabilitas perusahaan tersebut oleh karena itu, "para kreditur, pemilik perusahaan, dan khususnya pihak.

Kinerja keuangan merupakan suatu gambaran tentang kondisi keuangan yang dilihat dari laporan keuangan suatu perusahaan terutama laporan keuangan Laba Rugi, yang dianalisis dengan alat-alat analisis keuangan, sehingga dapat diketahui mengenai baik buruknya keadaan keuangan suatu perusahaan yang mencerminkan prestasi kerja dalam periode tertentu. Hal ini sangat penting agar sumber daya digunakan secara optimal dalam menghadapi perubahan lingkungan. Kinerja Keuangan perusahaan akan tercermin dalam nilai pasar sahamnya. Semakin tinggi harga saham semakin tinggi pula nilai perusahaan bagi perusahaan yang sudah go public karena nilai perusahaan dapat menunjukkan nilai aset yang dimiliki perusahaan seperti surat-surat berharga. Saham merupakan salah satu surat berharga yang dikeluarkan oleh perusahaan. Tinggi rendahnya harga saham banyak dipengaruhi oleh kondisi emiten. Salah satu faktor yang mempengaruhi harga saham adalah kemampuan perusahaan membayar dividen. Apabila dividen yang dibayar tinggi, harga saham cenderung tinggi sehingga nilai perusahaan juga tinggi. Sebaliknya bila dividen yang dibayarkan kecil maka harga saham perusahaan tersebut rendah sehingga nilai perusahaan rendah. Kemampuan membayar dividen erat hubungannya dengan kemampuan perusahaan memperoleh laba. Tinggi rendahnya harga saham ini juga merupakan refleksi dari keputusaninvestasi.

Permasalahan yang ada bahwa sebagian besar laporan laba rugi perusahaan yang dengan rasio keuangannya menunjukkan fluktuasi kenaikan dan penurunan, dimana hal ini menunjukkan bahwa kinerja keuangan dari perusahaan-perusahaan tersebut juga akan mengalami kenaikan dan penurunan, sehingga dapat dikatakan bahwa kinerja keuangan yang ada belum sepenuhnya baik karena kinerja yang baik menunjukkan fluktuasi kenaikan yang signifikan tanpa ada penurunan, hal ini juga sangat mempengaruhi penurunan nilai saham perusahaan di pasar bursa.

Penelitian yang dilakukan Husaini (2012) menunjukkan bahwa Pengaruh Variabel Net Profit Margin Return on Assets, dan Return on Equity terhadap Harga Saham Perusahaan kinerja keuangan perusahaan yang diukur dari NPM ROA,dan ROE, mempunyai pengaruh terhadap harga saham. Secara parsial dengan uji t disimpulkan bahwa secara parsial variable ROA yang berpengaruh secara signifian terhadap harga saham, sedangkan variabel NPM dan ROE tidak berpengaruh secara signifian terhadap harga saham. ROA mempunyai pengaruh dominan terhadap harga saham pada perusahaan yang termasuk dalam perusahaan Makanan dan Minuman.

Penelitian ini mencoba untuk meneliti seberapa besar pengaruhnya keempat variabel 
tersebut terhadap harga saham khususnya pada perusahaan industry Makanan dan Minuman yang terdaftar di Bursa Efek Indonesia.

Dengan Melihat hal di atas Baik Rata-rata pertumbuhan Penjualan,harga saham maupun rata-rata kinerja keuangan yang terdaftar di bursa efek Inonesia dan Bursa Efek Malaysia maka penulis tertarik untuk meneliti lebih jauh mengenai bagaimana pengaruh $\mathrm{CR}$, ROE, dan Sales Growth terhadap harga saham yang dituangkan dalam Judul "Pengaruh Current Ratio, Return On Equity ,Dan Sales Growth , Terhadap Harga Saham yang berdampak pada Kenerja Keuangan Perusahaan (kajian Empiris pada perusahaan makanan dan minuman pada 15 perusahaan Makanan \& Minuman Go Public di Indonesia).

\section{B. Perumusan Masalah}

Berdasarkan Identifikasi Masalah dan pembatasan masalah di atas, maka penulis merumuskan maslah sebagai berikut :

1. Bagaimana Pengaruh Current Ratio (CR) Terhadap Harga Saham pada perusahaan Makanan dan Minuman yang terdaftar di Bursa Efek Indonesia?

2. Bagaimana Pengaruh Retur On Equity (ROE) Terhadap Harga saham pada Perusahaan Makanan dan Minuman yang terdaftar di Bursa Efek Indonesia?

3. Bagaimana Pengaruh Sales Growth Terhadap Harga saham pada perusahaan Makanan dan Minuman yang terdaftar di Bursa Efek Indonesia?

4. Bagaimana Pengaruh Current Ratio, Return On Equity, dan Sales Growth Terhadap Harga saham secara Simultan?

5. Bagaimana Pengaruh Harga saham Terhadap Kinerja Keuangan yang terdaftar di Bursa efek Indonesia?

\section{Landasan Teori}

\section{Teori Tentang Current Ratio}

\section{a. Pengertian Tentang Current Ratio}

Menurut Van Hone (2001:39) Rasio Likuiditas (Liquidity Ratio) digunakan untuk mengukur kemampuan perusahaan untuk memenuhi kewajiban jangka pendeknya dengan sumber daya jangka pendek yang tersedia untuk memenuhi kewajiban tersebut, Menurut Moeljadi (2006:48) Rasio Likuiditas Istilah likuiditas menunjukkan kemampuan suatu perusahaan untuk memenuhi kewajiban-kewajiban keuangannya dalam jangka waktu pendek atau yang segera harus dibayar.Tingkat likuiditas yang tinggi menunjukkan bahwa perusahaan tidak mengalami kesulitan membayar kewajibannya dalam jangka waktu pendek, sehingga kreditur tidak perlu khawatir dalam memberikan pinjaman. Alat pemenuhan kewajiban keuangan jangka panjang ini berasal dari unsurunsur aktiva yang bersifat likuid, yakni aktiva lancar dengan perputaran < satu tahun, karena lebih mudah dicairkan daripada aktiva tetap yang perputarannya > satu tahun.

Current Rasio merupakan jenis rasio Likuiditas yakni Rasio yang menggambarkan kemampuan suatu perusahaan untuk melunasi semua kewajiban yang harus segera dipenuhi (Hutang jangka pendeknya) yakni dengan cara membandingkan aktiva lancar dengan hutang lancar.

Menurut Bambang Riyanto (2001:26), "Current ratio merupakan ukuran yang berharga untuk mengukur kesanggupan suatu perusahaan untuk memenuhi current obligation - nya

Menurut S. Munawir (2007:72), "Rasio lancar (Current ratio) yaitu perbandingan antara jumlah aktiva lancar dengan hutang lancar, rasio ini menunjukan bahwa nilai kekayaan lancar (yang segera dapat dijadikan uang) ada sekian kali hutang jangka pendek.

Menurut Agnes Sawir (2011:8), menerangkan bahwa Current ratio merupakan ukuran yang paling umum digunakan untuk mengetahui kesanggupan memenuhi kewajiban jangka pendek, karena rasio ini menunjukan seberapa jauh tuntutan dari kreditor jangka pendek dipenuhi oleh aktiva yang diperkirakan menjadi uang tunai dalam 
periode yang sama dengan jatuh tempo utang".

\section{Bursa Effek}

\section{a. Pengertian Bursa Efek}

Menurut nomor 8 tahun 1995, bursa efek adalah pihak yang mengyelenggarakan dan menyediakan sistem dan atau sarana untuk mempertemukan penawaran jual dan beli efek pihak-pihak lain dengan tujuan meperdagangkan efek diantara mereka.

Bursa Efek Menurut Marzuki Usman ( 1994 : 10) adalah wadah tempat bertemunya para broker dan dealer untuk melakukan jual beli efek (saham dan obligasi). Karena itu umumnya diluar negeri Bursa Efek itu diselenggarakan oleh swasta, bahkan pemiliknya adalah para broker dan dealer itu sendiri"

Menurut Christoni Tampubolon (2008:34) Bursa efek adalah sebagai wadah atau pasar tempat berlangsungnya proses kegiatan/ Transaksi perdagangan diantara pembeli dan penjual efek.

Menurut Sutrisno (2008:310) adalah bukti kepemilikan bagian modal atau tanda penyertaan modal pada perseroan terbatas, yang memberikan hak menurut besar kecilnya modal yang disetor.

Menurut Pengertian di atas Bursa Efek merupakan tempat pertemuan pencari modal dengan pihak yang memiliki uang dengan tujuan investasi.

Di Indonesia hanya ada satu bursa efek yaitu PT. Bursa Efek Indonesia (BEI) yaitu gabungan dari PT. Bursa Efek Jakarta dan PT. Bursa Efek Surabaya yang merger pada tahun 2010.

Bursa Efek Jakarta (BEJ) Merupakan Salah Satu Bursa Efek di Indonesia (BEI) yaitu tempat diamana orang memperjualbelikan efek di Indonesia. Dalam rangka memberikan informasi yang lebih lengkap tentang perkembangan bursa kepada publik, BEJ telah menyebarkan data pergerakan harga saham melalui media cetak dan elektronik. Satu indikator pergerakan harga saham tersebut adalah Indeks harga saham. BEI mempunyai 6 macam Indeks saham yaitu IHSG, Indeks Sektoral, Indeks LQ45, Indeks Individual, Jakarta Islamic Index dan Indeks Kompas 100.

\section{b. Fungsi Bursa Efek}

Menurut Agus Sartono (2010:23) Bursa Efek mempunyai beberapa fungsi yang perlu untuk diketahui, yaitu :

1) Menciptakan pasar secara terus menerus bagi efek yang telah ditawarkan kepada masyarakat.

2) Menciptakan Harga yang wajar bagi Efek yang bersangkutan melalui mekanisme pasar.

3) Membantu pembelanjaan dunia usaha melalui penghimpunan dana masyarakat.

4) Memperluas Proses perluasan partisipasi masyarakat dalam pemilikan saham-saham perusahaan.

\section{c. Tugas Bursa Efek}

Pemegang saham dan PT. Bursa Efek Indonesia (BEI) adalah perusahaan efek yang telah memperoleh Izin usaha sebagai perantara perdagangan efek. Sebagai Fasilitator, BEI mempunyai tugas yaitu :

1) Menyelenggarakan Perdagangan efek yang teratur, wajar dan efesien.

2) Menyediakan sarana pendukung serta mengawasi kegiatan anggota bursa efek.

3) Menyusun anggaran tahunan dan penggunaan laba bursa efek dan melaporkannya kepada Bapepam-L.K.

4) BEI Fokus pada perdagangan saham dan obligasi.

\section{Kinerja Keuangan}

\section{a. Pengertian Kinerja Keuangan}


Kinerja keuangan suatu perusahaan sangat erat kaitannya dengan penilaian mengenai sehat atau tidak sehatnya perusahaan tersebut.Apabila tingkat kinerjanya baik, maka baik pula tingkat kesehatan perusahaan.

Menurut Mulyadi (2012:20) " Kinerja keuangan adalah penentuan secara periodic efektifitas operasional suatu oerganisasi berdasarkan sasaran, standard dan criteria yang ditetapkan". Sedangkan Fahmi (2012:2) menjelaskan “ Kinerja keuangan adalah analisis yang dilakukan untuk melihat sejauh mana suatu perusahaan telah melaksanakan dengan menggunakan aturan-aturan pelakasanaan keuangan secara baik dan benar".

Pendapat Sawir (2012:15) "Kinerja keuangan adalah kondisi yang mencerminkan keadaan keuangan suatu perusahaan berdasarkan sasaran, standard an kinerja yang ditetapkan".

Dari beberapa pendapat di atas disimpulkan kinerja keuangan merupakan suatu prestasi yang dicapaui oleh perusahaan untuk selanjutnya dilakukan penilaian kinerja keuangan dengan cara melakukan analisis tetang baik buruknya keputusan sebagai gambaran mengenai hasil kinerja dan operasi perusahaan yang tertuang dalam laporan keuangan berdasarkan pada aturan-aturan yang berlaku secara baik dan benar sehingga dapat mencapai tujuan yang diharapkan perusahaan.

\section{b. Pengukuran Kinerja Keuangan}

Pengukuran kinerja keuangan mempunyai arti yang penting bagi pengambilan keputusan baik bagi pihak intern maupun ekstern perusahaan. Menurut Mulyadi (2012:419) mengemukakan :

Pengukuran kinerja adalah penentuan secara periodic tampilan perusahaan yang berupa kegiatan operasional, struktur organisasi, dan karyawan yang berdasarkan sasaran, standard an criteria yang telah ditetapkan sebelumnya, Pengukuran keuangan dapat dilakukan dengan menggunakan rasio keuangan yaitu Laporan Laba Rugi yakini Laba Bersih".

\section{c. Pengaruh Ukuran Perusahan dalam Laporan Keuangan}

Ukuran perusahaan adalah suatu skala dimana dapat diklasifikasikan besar kecil perusahaan menurut berbagai cara, antara lain : total aktiva, penjualan dan kapitalisasi pasar. Salah satu tolak ukur yang menunjukkan besar kecilnya perusahaan adalah ukuran total aset diperusahaan tersebut, semakin besar total aset maka semakin besar ukuran perusahaan tersebut (Diantimala, 2008). Perusahaan yang memiliki total aset besar menunjukkan bahwa perusahaan tersebut telah mencapai tahap kedewasaan dimana dalam tahap ini arus kas perusahaan sudah positif dan dianggap memiliki prospek yang baik dalam jangka waktu relatif lama, selain itu juga mencerminkan bahwa perusahaan relatif lebih stabil dan lebih mampu menghasilkan laba dibanding perusahaan dengan total aset yang kecil (Khairuna, 2014). Kondisi yang stabil diharapkan memberi return yang tinggi kepada pemegang saham. Semakin besar ukuran perusahaan maka semakin Baik. Tujuan utama perusahaan menurut theory of the firm adalah untuk memaksimumkan Profit atau nilai perusahaan (value of firm) (Salvatore, 2005 dalam Subana, 2016). Perusahaan ada karena akan menjadi sangat tidak efisien mahal bagi pengusaha untuk masuk dan membuat kontrak dengan pekerja dan para pemilik modal, tanah dan sumber daya lain untuk setiap tahap produksi dan distribusi yang terpisah. Sebaliknya, pengusaha biasanya masuk dalam kontrak yang besar dan berjangka panjang dengan tenaga kerja untuk mengerjakan berbagai tugas dengan upah tertentu dan berbagai tunjangan lain. Kontrak yang umum semacam itu jauh lebih murah ketimbang sejumlah kontrak spesifik dan sangat menguntungkan baik bagi pengusaha maupun pekerja dan pemilik sumber daya lain. Perusahaan ada karena untuk menghemat biaya transaksi semacam itu. Dengan menginternalisasiberbagai transaksi (yaitu dengan menjalankan 
berbagai fungsi dalam perusahaan), perusahaan juga menghemat pajak penjualan dan menghindari control harga dan peraturan pemerintah yang berlaku hanya untuk traksaksi antar perusahaan.

Laba atau profit dalam ilmu ekonomi murni didefinisikan sebagai peningkatan kekayaan seseorang investor sebagai hasil penanam modalnya, setelah dikurangi biaya-biaya yang berhubungan dengan penanaman modal tersebut (termasuk didalamnya, biaya kesempatan) Untuk memaksimalkan laba yang diperoleh setiap perusahaan bisa dicapai melalui bermacam-macam cara antara lain ialah melalui efisiensi di semua bidang, seperti produksi, sumber daya manusia, maupun keuangan. Dalam teori ekonomi mikro, tujuan perusahaan adalah mencari keuntungan secara teoritis laba adalah kompensasi atau resiko yang di tanggung oleh perusahaan, semakin besar resiko semakin pula laba yang di peroleh. Perusahaan yang memaksimalkna keuntungan disemua industri harus menentukan tiga pilihan seperti : berapa banyak output yang akan ditawarkan, bagaimana memproduksi output itu dan berapa banyak tipa input yang akan diminta. Kita mengasumsikan bahwa perusahaan menjalankan bisnis untuk mencetak laba. Laba sama dengan penerimaan total dikurangi biaya total. Biaya total atau biaya ekonomis meliputi biaya yang benar-benar dikeluarkan faktor produksi Perusahaan yang memaksimalkan laba akan memilih kombinasi input yang meminimalkan biaya dan memaksimalkan laba. Pengusaha harus mampu mengatur manajemen keuangan agar mengetahui kendala-kendala biaya produksi lainnya. Memaksimalkan laba dengan strategi yang tepat akan memudahkan perusahaan untuk dapat bersaing dalam era globalisasi sekarang. Sasaran utama strategi pencapaian laba perusahaan \&efisiensi modal usaha yang efektif yaitu Seberapa besar presentase laba yang diperoleh dibandingkan dengan jumlah modal sendiri yang diinvestasikan dalam perusahaan, dan seberapa besar perputaran modal kerja dalam satu periode tertentu misalnya dalam satu tahun. Pada intinya tujuan dari memaksimalkan laba adalah mencari keuntungan bagi perusahaan tersebut yang sedang produksi.

\section{Hipotesis Penelitian}

Menurut Sugiyono (2008:93), Menyatakan bahwa hipotis adalah jawaban sementara terhadap rumusan masalah dalam penelitian. Dikatakan sementara karena jawaban yang diberikan baru didasarkan pada teori-teori relevan, belum didasarkan fakta empiris yang diperoleh melalui pengumpulan data.

\section{Ruang Lingkup Penelitian}

\section{a. Tempat Penelitian}

Menurut Sugiyono (2014:13) tempat penelitian adalah "Sasaran ilmiah untuk mendapatkan data dengan tujuan dan kegunaan tertentu tentang sesuatu hal objektif, valid dan reliable tentang sesuatu hal (variabel tertentu)".

Lokasi penelitian dilakukan di Bursa Efek Indonesia (pada tahun 2012 - 2017 dengan mengambil data dari situs internet www.idx.co.id www.sahamok.com. dan www.investing.com

\section{b. Waktu Penelitian}

Waktu Penelitian ini dilaksanakan selama 5 (tiga) bulan yang dimulai dari bulan Desember 2017 sampai dengan Mei 2018. Adapun penelitian dilakukan secara bertahap disesuaikan dengan tingkat kebutuhan penulis.

\section{c. Sifat Peneletian}

Jenis Penelitian ini adalah deskriptif dengan pendekatan asosiatif, menurut Sugiyono (2014:44) yaitu "Penelitian yang bertujuan untuk mengetahui pengaruh atau hubungan antaradua variabel atau lebih".Penelitian asosiatif mempunyai tingkatan yang lebih tinggi bila dibandingkan dengan deskriptif dan komparatif.Dengan penelitian asosiatif ini maka dapat dibangun suatu teori yang berfungsi untuk menjelaskan, meramalkan dan rnengontrol suatu gejala. 


\section{Populasi dan Sampel}

\section{a. Populasi}

Menurut Menurut Sugiyono (2014:119) "Populasi adalah jumlah wilayah generalisasi yang terdiri atas obyek atau subyek yang mernpunyai kualitas dan karakteristik yang ditetapkan oleh peneliti dan kernudian ditarik kesimpulannya", menurut Jonathan Sarwono (2012:18) "Populasi rnerupakan kesatuan yang rnernpunyai karakteristik yang sama dirnana sarnpel akan kita tarik". Sedangkan rnenurut Suharsimi Arikunto (2010:173) mendefinisikan "Populasi adalah keseluruhan subjek penelitian".Dan menurut Husen Umar (2013:140) "Populasi adalah kurnpulan elemen yang mernpunyai karakteristik yang sama dan mempunyai kesempatan yang sama untuk dipilih menjadi sampel".

Dari pengertian diatas, dapat disimpulkan bahwa populasi bukan sekedar jumlah yang ada pada objek atau subjek yang dipelajari, tetapi meliputi seluruh karakteristik atau sifat yang dirniliki oleh subjek atau objek tersebut. Jadi populasi bukan hanya orang tetapi juga obyek dan berbeda-beda alam yang lain. Populasi juga bukan sekedar jumlah yang ada pada obyek/subyek yang dipelajari, tetapi meliputi seluruh karakteristik/sifat yang dimiliki oleh subyek atau obyek itu.Dalam penelitian ini yang dijadikan populasi adalah laporan keuangan (yang sudah dibuat berupa data panel) 15 perusahaan manufaktur sektor Makanan dan Minuman di Bursa Efek Indonesia yang secar berturut-turut memberikan laporan keuangan secara periodik selama periode penelitian 2012-2017

Tabel 3.1

Perusahaan Manufaktur Makanan dan Minuman di Bursa Efek Indonesia Dalam Rupiah

\begin{tabular}{|c|c|l|c|}
\hline No & $\begin{array}{c}\text { Kode } \\
\text { Perusahaan }\end{array}$ & \multicolumn{1}{|c|}{ Perusahaan tercatat } & $\begin{array}{c}\text { Rata-rata Laba Rugi } \\
\mathbf{( 2 0 1 2 - 2 0 1 7 )}\end{array}$ \\
\hline 1 & ADES & Akasha Wira International tbk & $\mathbf{2 6 5 . 2 6 8}$ \\
\hline $\mathbf{2}$ & AISA & Tiga Pilar Sejahtera Food Tbk & $\mathbf{1 . 8 3 3 . 6 2 8}$ \\
\hline 3 & ALTO & Tri Banyan Tirta Tbk & $\mathbf{( 4 2 . 7 9 8 )}$ \\
\hline 4 & CEKA & Cahaya Kalbar Tbk & $\mathbf{5 3 8 . 5 6 5}$ \\
\hline 5 & DAVO & Davomas Abadi Tbk & $\mathbf{1 . 2 6 5 . 1 7 6}$ \\
\hline 6 & DLTA & Delta Djakarta Tbk & $\mathbf{1 4 . 1 9 4 . 0 7 0}$ \\
\hline 7 & ICBP & Indofod CBP Sukses Makmur & $\mathbf{1 9 . 9 4 5 . 1 4 3}$ \\
& & Tbk & $\mathbf{4 . 1 1 8 . 5 2 8}$ \\
\hline 8 & INDF & Indofood Sukses Makmur Tbk & $\mathbf{5 . 1 2 3 . 4 0 7}$ \\
\hline 9 & MLBI & Multi Bintang Indonesia Tbk & $\mathbf{( 5 9 . 5 6 4 )}$ \\
\hline 10 & MYOR & Mayora Indah Tbk & $\mathbf{1 . 0 7 0 . 5 7 2}$ \\
\hline 11 & PSDN & Prashida Aneka Niaga Tbk & $\mathbf{2 2 7 . 0 9 5}$ \\
\hline 12 & ROTI & Nippon Indosari Corporindo Tbk & $\mathbf{8 0 . 7 8 6}$ \\
\hline 13 & SKBM & Sekar Bumi Tbk & $\mathbf{7 0 8 . 4 1 5}$ \\
\hline 14 & SKLT & Sekar Laut Tbk & $\mathbf{2 . 3 1 3 . 1 6 0}$ \\
\hline 15 & STTP & Siantar Top & Ultra Jaya Milk Industry and \\
\hline 16 & ULTJ & Trading Company & \\
& &
\end{tabular}

Sumber : Bursa Efek Indonesia, Sub Sector Makanan dan Minuman 2012-2017

\section{b. Sampel}

Model sampel yang digunakan pada penelitian ini adalah teknik non probability sampling yang digunakan dalam pengambilan sampel pada penelitian ini yaitu teknik purposive sampling. Pengertian purposive sampling menurut Sugiyono (2014:122) adalah "Teknik penentuan sampel dengan pertimbangan tertentu. yang 
merupakan teknik pengambilan sampel non random sampling." Non random sampling mempunyai arti bahwa pengambilan sampel yang tidak semua anggota populasi mendapat kesempatan untuk dipilih menjadi sampel. Metode purposive sampling harus menentukan kriteria yang ditentukan untuk mendapatkan sampel yang representative. Kriteria yang ditetapkan dalam pengambilan sampel pada penelitian ini ditentukan sebagai berikut :

1) Perusahaan Manufaktur Makanan dan Minuman yang menerbitkan laporan keuangan tahun 2012 sampai 2017.

2) Perusahaan yang memiliki nilai Current Ratio (CR), Return On Equity (ROE) dan Sales Growth terhadap Harga Saham dan Kinerja Keuangan

\section{E. Hasil Analisis Data dan pembahasan}

\section{Analisis Data (Sub Struktur 1)}

Pada bagian analisis data pada sub struktur 1 dimaksudkan untuk mengetahui pengaruh variabel Current Ratio (X1), Return On Equity (X2) dan Sales Growth (X3) terhadap Harga Saham $(Y)$ dan dampaknya pada Kinerja Keuangan Perusahaan (Z). Rancangan analisa yang akan dipakai dalam penelitian ini pada Sub struktur 1ini adalah dengan memakai analasis sebagai berikut:

\section{a. Analisis Regresi Linier Berganda}

Menurut Sugiyono (2014:153) mengemukakan bahwa "Analisis regresi digunakan untuk melakukan prediksi bagaimana perubahan nilavariable dependen bila nilai variable independen dinaikan/diturunkan". Sedangkan menurut Santoso dan Ashari (2005:47), mengemukakan bahwa "Analisis regresi berganda merupakan persamaan regresi dengan menggunakan dua data atau lebih variable bebas".Sedangkan menurut pendapat Ghozali (2013:82) mengemukakan "Analisis regresi berganda digunakan untuk rnengetahui ada tidaknya pengaruh variable bebas terhadap variabel terikat terhadap".

Dalam Penelitian ini analisis Linear berganda digunakan untuk membuktikan

sejauh mana hubungan Current Ratio, Return On Equity dan Sales Growth

Terhadap Harga Saham yang Berdampak pada Kinerja Keuangan Perusahaan.

Berkaitan dengan hal tersebut model hubungan ini disusun dalam fungsi atau persamaan regresi ganda (multiple linier regression method) yang dirurnuskan sebagai berikut (Sugiyono, 2012: 192).

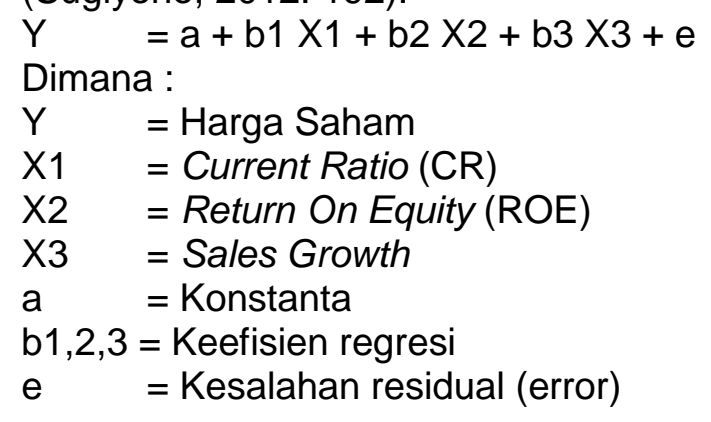

\section{b. Analisis Koefisien Determinasi ( Sub-Struktur 1)}

Pengertian koefisien determinasi menurut Andi Supangat (2008:350) berpendapat "Merupakan besaran untuk menunjukkan tingkat kekuatan hubungan antara dua variabel atau lebih dalalm bentuk persen". Berdasarkan dari pengertian diatas, maka koefisien determinasi merupakan bagian dari keragaman total darivariabel terikat yang dapat diperhitungkan oleh keragaman variabel bebas dihitung dengan koefisien determinasi dengan asumsi dasar faktor- faktor laindiluar variabe1 dianggap konstan. KD merupakan besaran nol negatif.Besarnya nilai koefisien determinasi adalah antara 0-1. Koefisien determinasi bernilai nol berarti tidak ada hubungan antara variabel X1, X2 dan X3 (bebas) dengan variabel $Y$ (terikat), dan sebaliknya nilai koefisien determinasi 1 berarti suatu 
kecocokan yang sempurna dari ketepatan perkiraan model yang dihitung suatu koefisien yang disebut koefisien penentuan,

\section{Rancangan Pengujian Hipotesis}

Uji hipotesis diperlukan untuk menguji apakah variabel independen berpengaruh terhadap variabel dependen. Menurut Sugiyono (2014:213) pengertian hipotesis adalah "Hipotesis merupakan jawaban sementara terhadap rumusan masalah penelitian, oleh karena itu rumusan masalah penelitian biasanya disusun dalam bentuk kalimat pertanyaan". Dengan demikian hipotesis penelitian dapat diartikan sebagai jawaban yang bersifat sementara terhadap masalah penelitian, sampai terbukti melalui data yang terkumpul dan harus diuji secara empiris.

a. Pengujian Hipotesis Secara Parsial (Uji t)

Hubungan variable independen secara parsial dengan variabel dependen, dapat diuji dengan uji $t$ dengan membandingkan $t$ hitung dengan $t$ tabel. Adapun rumus yang digunakan menurut Sugiyono (2014:184) dalam menguji hipotesis (Uji t) penelitian ini

$$
\mathrm{r}=\frac{\mathrm{R} \sqrt{ }}{\sqrt{ }}
$$

adalah :

$$
\begin{aligned}
& \text { Keterangan : } \\
& \mathrm{t}=\text { Probabilitas } \\
& \mathrm{r}=\text { Koefisien Korelasi } \\
& \mathrm{n}=\text { Jumlah }
\end{aligned}
$$

Pengujian hipotesis dilakukan dengan membandingkan nilai $t$ hitung dengan t table dengan tingkat signifikansi $0,05(5 \%)$ dan derajat bebas $n-4$ dengan kriteria sebagai berikut:

1) Jika thitung $>$ ttabel pada $\alpha=5 \%$ maka $\mathrm{HO}$ ditolak dan $\mathrm{H} 1$ diterima (berpengaruh)

2) Jika thitung $<$ ttabe1pada $\alpha=5 \%$ maka $\mathrm{H} 0$ diterima dan $\mathrm{H} 1$ ditolak(tidak berpengaruh).

Kesimpulan mengenai diterirna tidaknya hipotesis setelah dibandingkan antara thitung dan ttabel dengan hipotesis sebagai berikut:

\section{a) Variabel Current Ratio (X1)}

$\mathrm{H} 0: \rho 1=0$ Current Ratio $(\mathrm{CR})$ tidak berpengaruh positif dan signifikan terhadap Harga Saham.

$\mathrm{H} 1: \rho 1 \neq 0$ Current Ratio (CR) berpengaruh Positif dan signifikan terhadap Harga Saham

\section{b) Variabel Return On Equity (X2)}

$\mathrm{H} 0: \rho 1=0$ Return On Equity (ROE) tidak berpengaruh positif dan sginifikan terhadap Harga Saham.

$\mathrm{H} 1: \rho 1 \neq 0$ Return On Equity ( $\mathrm{ROE}$ ) berpengaruh Positif dan signifikan terhadap Harga Saham.

c) Variabel Sales Growth (X3)

$\mathrm{H} 0: \rho 1=0$ Sales Growth tidak berpengaruh Positif dan Signifikan terhadap Harga Saham.

$\mathrm{H} 1: \rho 1 \neq 0$ Sales Growth berpengaruh positif dan Signifikan terhadap Harga Saham.

\section{b. Pengujian Hipotesis Secara Simultan ( Uji F)}

Uji F digunakan untuk mengetahui ada dan tidaknya pengaruh bersama (simultan) CR, ROE, sales growth terhadap harga saham. Menurut Sugiyono (2012:223) mengemukakan bahwa "Uji $F$ digunakan untuk mengetahui pengaruh secara bersama-sama variabel independen terhadap variable dependen". Untuk menguji adanya hubungan antara variabel bebas (X1, X2, dan $\mathrm{X} 3$ ) secara simultan berdampak terhadap variabel terikat $(\mathrm{Y})$ dilakukan penghitungan dengan rumus sebagai berikut: 
Fhitung $=$

$/ \mathrm{k}$

$$
(1-/(\mathrm{n}-\mathrm{k}-1)
$$

Sumber : Sugiyono (2012:223)

Dimana :

$$
\begin{array}{ll}
\mathrm{R} 2 & =\text { Koefisien Korelasi ganda } \\
\mathrm{k} & =\text { Jumlah Variabel Indevenden } \\
\mathrm{n} & =\text { Jumlah data }
\end{array}
$$

Untuk menguji adanya hubungan antara variabel bebas ( $\mathrm{X} 1, \mathrm{X} 2$, dan $\mathrm{X} 3$ ) secara simultan berdampak terhadap variabel terikat $(Y)$ rnaka pengujian dilakukan dengan menggunakan uji statistik F dengan langkah- langkah sebagai berikut:

1) Menentukan hipotesis secara simultan atau keseluruhan antara variabel bebas terhadap variabel terikat.

2) Menentukan nilai signifikansi yaitu sebesar $5 \%(0,05)$ dan derajat bebas ( $\mathrm{df}=$ $\mathrm{n}$ - 4), untuk mengetahui daerah $\mathrm{F}$ tabel sebagai batas daerah penolakan, adapun rumusan hipotesisnya adalah:

H0 : b1,2,3 = 0 Current ratio, Return on equity dan Sales Growth ratio secara simultan tidak berpengaruh positif dan signifikan terhadap Harga Saham Penutup.

Kesimpulan Pengujian Model Regresi Data Panel

\begin{tabular}{|l|l|l|l|}
\hline No & Metode & Pengujian & Hasil \\
\hline 1. & Chow-Test & Common Effect vs Fixed Effect & $\begin{array}{l}\text { Fixed } \\
\text { Effect }\end{array}$ \\
\hline 2. & $\begin{array}{l}\text { Langrage Multiplier } \\
\text { (LM-test) }\end{array}$ & $\begin{array}{l}\text { Common Effect vs Random Effect } \\
\text { Effect }\end{array}$ \\
\hline 3. & Hausman Test & Fixed Effect vs Random Effect & $\begin{array}{l}\text { Random } \\
\text { Effect }\end{array}$ \\
\hline
\end{tabular}

Sumber : data yang diolah (2018)

\section{A. Hasil Estimasi Model Random Effect}

Estimasi terhadap ketiga model regresi data panel, tujuannya untuk memperkuat kesimpulan pengujian berpasangan, yang merekomendasikan penggunaan model efek random yang akan dianalisis lebih lanjut dalam penelitian ini.

\section{Model Efek Random}

Estimasi regresi data panel dengan model efek random membuktikan bahwa variable bebas yaitu Curret Ratio (CR), Return On Equity (ROE) dan Sales Growth bersama-sama berpengaruh positif dan signifikan terhadap harga saham.

\section{Uji Multikolinearitas (Multicolinearnity)}

Permasalahan multikolinearitas telah dapat terselesaikan ketika menggunakan data panel atau dengan kata lain data panel menjadi solusi jika data tersebut mengalami multikolinearitas (Gujarati 20013, dalam Marnindianti Novan, 2009). Namun untuk memperkuat pernyataan tersebut, telah dilakukan uji multikolinearitas dengan menggunakan correlation matrix berikut.

Tabel 4.11

Tabel Correlation Matrix Variabel Independen

\begin{tabular}{|l|c|c|c|}
\hline & CR & ROE & SALES_GROWTH \\
\hline CR & 1 & 0.497382 & -0.021651 \\
\hline ROE & 0.497382 & 1 & 0.018755 \\
\hline SALES_GROWTH & -0.021651 & 0.018755 & 1 \\
\hline
\end{tabular}

Sumber: Hasil output data Panel Eviews 9.0 - 2018

Tabel di atas memperlihatkan bahwa tidak terdapat hubungan antara variabel bebas dengan nilai lebih dari 0,8. Data dikatakan teridentifikasi multikolinearitas apabila koefisien korelasi antar variabel independen lebih dari satu atau sama dengan 0,8 (Gujarati 2013 
dalam Marnindianti Novan, 2009). Sehingga dapat disimpulkan bahwa antara variabel bebas terdapat multikolinearitas. Dengan demikian, data panel dalam penelitian ini telah tidak terbebas dari masalah heterokedastisitas (heterocedasticity), autokorelasi (autocorrelation), dan multikolinearitas (multicollinearity).

\section{B. Regresi Data Panel untuk Variabel Dependen (Harga Saham)}

Berdasarkan hasil estimasi yang terbaik menggunakan kriteria koefisien determinasi $\mathrm{R} 2$ dan koefisien determinasi yang disesuaikan $\mathrm{R} 2$, maka model regresi data panel yang digunakan dalam mengestimasi faktor-fakor yang mempengaruhi harga saham pada industri manufaktur makanan dan minuman yang tercatat di Bursa Efek Indonesia dalam penelitian ini adalah model efek random.

1. Estimasi Model Regresi Data Panel Secara Parsial (Uji t)

Hasil estimasi faktor-faktor yang mempengaruhi harga saham, yaitu Current Ratio, Return On Equity (ROE), Sales growth menggunakan model random seperti yang ditunjukan dalam tabel 4.8 dapat ditulis dalam bentuk persamaan berikut ini :

Estimation Command:

LS(CX=R, COV=CXSUR) SAHAM CR ROE SALES_GROWTH

Estimation Equation:

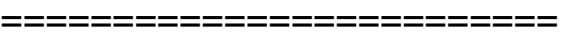

$\mathrm{SAHAM}=\mathrm{C}(1)+\mathrm{C}(2)^{*} \mathrm{CR}+\mathrm{C}(3)^{\star} \mathrm{ROE}+\mathrm{C}(4)^{\star} \mathrm{SALES}$ _GROWTH +

[CX=R,ESTSMPL="2012 2017"]

Substituted Coefficients:

$========================$

SAHAM $=2330.30750786-259.68067524^{*} \mathrm{CR}+171.778579408^{*} \mathrm{ROE}-$

127.639773792*SALES_GROWTH + [CX=R,ESTSMPL="2012 2017"]

Dari persamaan (4.1), selanjutnya kita melakukan pengujian terhadap mesing-masing koefisien regresi data panel yang mempengaruhi harga saham pada industri manufaktur makanan dan minuman dengan menggunakan uji-t. Uji-t dilakukan untuk menentukan apakah masin- masing variabel bebas yang digunakan dalam penelitian ini dapat mempengaruhi harga saham sebagai variabel terikat $(\alpha=0,01 \alpha=0,05$ atau $\alpha=1)$. Untuk variabel yang signifikan akan diinterperstasikan masing-masing dan dibandingkan dengan hipotesis penelitian. Pengujian ini akan dilakukan dengan dua tahap uji bagi masing-masing variabel bebas pada model penelitian ini, yaitu uji signifikan dengan harga saham atas $p$-value dan uji arah atas nilai koefisiennya.

\section{Hipotesis 1}

\section{Pengaruh Current Ratio terhadap harga saham}

Untuk menguji pengaruh parsial tersebut dapat dilakukan dengan cara sebagai berikut :

1. Jika nilai signifikan lebih kecil dari 0,05 atau $5 \%$ maka hipotesis yang diajukan diterima atau dikatakan signifikan.

2 Jika nilai signifikan lebih besar dari 0,05 atau 5\% maka hipotesis yang diajukan ditolak atau dikatakan tidak signifikan.

\section{F. Kesimpulan dan Saran}

\section{Kesimpulan}

Berdasarkan pembahasan dan hasil penelitian mengenai pengaruh Current Ratio, Return On Equity dan Sales Growth terhadap Harga Saham dan dampaknya terhadap Kinerja Keuangan pada perusahaan industry manufaktur makanan dan minuman yang tercatat di Bursa Efek Indonesia pada periode dari tahun 2012 sampai 2017, maka dapat diperoleh beberapa kesimpulan sebagai berikut :

1) Current Ratio $(C R)$ berpengaruh negatif dan signifikan terhadap Harga Saham. Hal ini dapat dilihat dari hasil Eviews yang menunjukkan dengan hasil uji parsial sebesar 
nilai Prob variabel Current Ratio (CR) 0,0174 yang kurang dari 0,05 sehingga variabel bebas CR terhadap Harga Saham berpengaruh negatif dan signifikan terhadap variabel terikat pada alpha $<5 \%$ pada nilai coefificient sebesar (1500.294)

2) Return On Equity berpengaruh positif dan signifikan terhadap harga saham . Hal ini dapat dilihat dari hasil Eviews yang menunjukkan dengan hasil uji parsial dengan koefisien 170,6992 positif (+) dengan probabilitas sebesar 0,0000 lebih kecil dari 0,05 atau $5 \%$ maka hipotesis yang diajukan diterima atau dikatakan signifikan terhadap harga saham.

3) Sales Growth berpengaruh positif dan tidak signifikan terhadap harga saham. Hal ini dapat dilihat dari hasil Eviews yang menunjukkan dengan nilai koefisien 74.4211 dengan probabilitas sebesar 0,7303 lebih besar dari 0,05 atau $5 \%$ maka hipotesis yang di ajukan ditolak atau dikatakan tidak signifikan terhadap harga saham.

4) Current Ratio (CR), Return On Equity (ROE) dan Sales Growth secara bersamasama (simultan) berpengaruh positif dan signifikan terhadap Harga Saham. Hal ini dapat dilihat dari hasil Eviews yang menunjukkan dengan hasil uji-F menunjukkan bahwa variabel Current Ratio (CR), Return On Equity (ROE) dan Sales Growth dengan F- statistik sebesar 20,94081 dengan nilai probabilitas sebesar 0,0000 lebih kecil dari 0,05 atau 5\% maka hipotesis yang di ajukan diterima atau dikatakan signifikan terhadap harga saham pada industri manufaktur makan dan minuman selama periode 2012-2017. Maka hasil penelitian ini menunjukan positif dan signifikan dengan tingkat keyakinan sebesar 0,422 atau $42 \%$ dan sisanya $58 \%$ dipengaruhi oleh faktor-faktor lain diluar model ini. dimana nilai probabilitas $F$ - statistic 0,0000 kurang dari $\mathrm{a}=0,05$ yang berarti $\mathrm{H} 4$ diterima atau positif dan signifikan.

5) Harga saham berpengaruh positif dan signifikan terhadap Kinerja Perusahaan. Hal ini dapat dilihat dari hasil Eviews yang menunjukkan dengan hasil uji parsial Berdasarkan uji-t menunjukkan bahwa variabel harga saham dengan koefisien 119.374 positif (+) dengan probabilitas sebesar 0,000 kurang dari 0,05 atau 5\% maka hipotesis yang di ajukan diterima atau dikatakan signifikan terhadap kinerja keuangan

\section{B. Saran}

Saran dalam penelitian ditujukan bagi peneliti selanjutnya yang berminat mengembangkan studi ini untuk memberikan variasi yang berbeda dan hasil yang lebih baik terkait dengan faktor-faktor yang mempengaruhi nilai perusahaan. Beberapa saran yang dapat direkomendasikan untuk manajerial dan peneliti selanjutnya.

\section{Bagi Perusahaan}

Berdasarkan hasil penelitian menunjukan adanya pengaruh yang signifikan dari Current Ratio, Return On Equity, Sales Growth, Harga Saham dan Kinerja Keuangan. Berdasarkan hasil tersebut, maka diharapkan perusahaan yang menjadi subjek dalam penelitian ini ataupun di luar penelitian ini, untuk dapat memperlihatkan faktor-faktor tersebut untuk dapat memperhatikan tingkat hutang maupun mengoptimalkan laba perusahaan. Sehinggga yang dapat dilakukan manajer keuangan dalam meningkatkan profit agar kinerja maupun nilai perusahaan menjadi meningkat. Jika nilai perusahaan baik, maka tingkat profitabilitas perusahaan juga akan meningkat.

$\mathrm{Hal}$ ini disebabkan oleh adanya kontrol yang mereka miliki oleh investor perusahaan diharapakan perusahaan juga akan meningkat. Hal ini disebabkan oleh adanya kontrol yang mereka miliki. Aspek kontrol yang dimiliki investor perusahaan diharapakan akan dapat berpengaruh terhadap nilai perusahaa.

\section{Bagi Investor}

Investor hendaknya memperhatikan tingkat profitabilitas perusahaan, selain itu juga perlu memperhatikan kinerja keuangan didalam suatu perusahaan. Kinerja keuangan merupakan corporate action yang penting, yang harus dilakukan perusahaan. Kebijakan tersebut dapat menentukan berapa banyak keuntungan yang akan diperoleh pemegang saham. 


\section{Bagi Peneliti Selanjutnya}

Keterbatasan dalam penelitian ini hendaknya dapat disempurnakan dan dikembangkan dengan menggunakan sampel perusahaan lebih baik yang terdaftar di Bursa Efek Indonesia. Hasil penelitian yang diharapkan nantinya, kita bisa mengetahui apakah faktor-faktor yang berpengaruh terhadap kinerja perusahaan sama ataukah berbeda antar sektor di luar ruang lingkup perusahaan industry manufaktur logam. Selain itu, disarankan kepada peneliti selanjutnya untuk memperluas variabel keuangan lainnya yang memiliki pengaruh lebih besar terhadap nilai perusahaan.

\section{G. Daftar Pustaka}

Agnes, Sawir. 2008. "Analisis Kinerja Keuangan dan Perencanaan Keuangan". Jakarta: Pt Gramedia Pustaka Utama.

Agus Sartono. 2008, "Manajemen Keuangan Teori Dan Aplikasi", Edisi 4, Penerbit : BPFE, Yogyakarta

Al Muizzudin F., SE., ME., "Praktikum Asumsi Klasik Regressi OLS, Unbraw, 2014

Anoraga, Pandji. 2000. "Manajemen Bisnis" Jakarta: Rineka Cipta

Arifin, Ali, "Membaca saham (Paduan Dasar Seni Berinvestasi)", PT. Andi. Yogyakarta, 2007

Bagus, Ogi“Pengaruh Return On Equity, Pertumbuhan Penjualan, Deviden dan Inflasi Terhadap Harga Saham di Bursa Efek Indonesia tahun ( per 2009-2013”, e Proceding Of Management : Vol.2 Tesis, Universitas Telkom, 2015

Bastian, Indra, "Akuntansi Sektor Publik", Erlangga, Jakarta, 2006

Birgham, F. Eugene \& Joel F. Houston. 2010, "Dasar-dasar Manajemen Keuangan". Edisi II \& Buku 1, Penerbit : Salemba Empat, Jakarta.

Boediono, "Ekonomi Indonesia, Mau Kemana?. Kumpulan Essai Ekonomi, Kepustakaan Populer", Gramedia, 2009.

Daft, Richard.L., Marcic, Dorothy,"Understanding Management", 12 Edition, McGraw Hill Education, Newyork, 2007

Darsono. 2009, “Manajemen Keuangan”, Penerbit : Nusantara Consulting, Jakarta.

Fahmi, Irfan, "Analisis Kinerja Keuangan Cetakan kesatu”, Alfabeta, Bandung, 2011

Ghozali, Imam, "Aplikasi Analisis Multivariate dengan Program SPSS. Cetakan III", Badan Penerbitan Universitas Diponegoro, Semarang, 2005

Gitosudarmo, Indrio, “Manajemen Keuangan Edisi 4", BPFE, Yogyakarta, 2002

Griffin, Ricky W. 2004. "Manajemen. Edisi Kesepuluh”. Jakarta: Erlangga.

Gujarati, Damodar N, “ Basic Econometrics”, Mc Graw Hill, inc, Singapura, 2003

Hadi, Noor, "Pasar Modal (Acuan Teoritis dan Praktis Investasi di Instrumen Pasar Modal)", Graha Ilmu, Yogyakarta, 2013

Harahap, S.S, "Analisa kritis atas laporan keuangan, Edisi I Cetakan 6", PT. Raja Grafindo Persada, Jakarta, 2008

Harjito, Agus dan Martono, "Manajemen Keuangan", Edisi Kedua cetakan pertama, Ekonisisa, Yogyakarta, 2010

Hermansyah, Irwan "Pengaruh Harga Saham Terhadap Laba Bersih" (Pada Perusahaan makanan dan Minuman yang Terdaftar di Bursa Efek Indonesia Tahun 20062008", Tesis Univ Siliwangi Tasikmalaya

Horne, James C. Van, dan John M. Machowicz, Jr, "Prinsip-prinsip Manajemen Keuangan (Edisi ke 13)", Salemba Empat, Jakarta, 2012

http://idx.co.id akses diwebsite tgl 04 mei 201816.43

http://Investing.com akses diwebsite tgl 04 mei 201816.44

http://sahamoke.com/ akses diwebsite tgl 04 mei 201816.46

Husnan, Suad dan Enny “Dasar-Dasar Manajemen”, Edisi ke Tujuh Cetakan Pertama, Yogyakarta 2015

Ikatan Akuntan Indonesia, 2004. Standar Akuntansi Keuangan. PSAK No. 17, Penerbit Salemba Empat, Jakarta. 
Jogiyanto, "Teori Portofolio dan Analisis Investasi", edisi kedua, Penerbit BPPE. Yogyakarta, 2008.

Kadim, A., \& Sunardi, N. (2018). Pengaruh Analisa Kesahatan dan Kebangkrutan Dengan Pendekatan ALtman Z-Score Terhadap Harga Saham Industri Konstruksi di Indonesia yang Listing di BEI Periode 2013-2017. Jurnal SEKURITAS (Saham, Ekonomi, Keuangan dan Investasi), 1(4).

Kasmir, "Analisis Laporan Keuangan", Rajawali Persada, Jakarta, 2008

Kerlinger, Fred N, 2006. "Asas-Asas Penelitian Behavioral". Penerbit Universitas Gadjah Mada. Yogyakarta.

M. Aditya Ananda,"Analisis CAR, FDR, NPF dan BOPO terhadap ROA BUS (Studi kasus pada BUS di Indonesia tahun 2010-2012", Tesis, IAIN Sumatera Utara, 2013

Made, I Wiratha, "Metode Penelitian Sosial Ekonomi”, Andi Offset, Yogyakarta, 2002

Manullang M, 2006, Dasar-Dasar Manajemen, edisi revisi, cetakan ketujuh, Penerbit : Ghalia Indonesia, Jakarta

Muliawati, Sri dan Moh. Khoiruddin, "Faktor-Faktor Penentu Profitabilitas Bank Syariah di Indonesia", Management Analysis Journal 4 (1) Univ. Negri Semarang, 2015

Muljadi., "Great Cash Management Great Profit", Edisi 2 Cetakan 1, Salemba Raya Jakarta, 20013

Munawir, "Analisa Laporan Keuangan", Edisi Kedua, YKPN, Yogyakarta, 2002

Murni,Sri, "Analisis Pengaruh Current Ratio, Return On Equity, Debt To Equity Ratio dan Sales Growth terhadap Return Saham pada Cosmetic dan HouseHold Industry di Bursa Efek Indonesia (Per 2010-2016)

Nasaruddin, M.Irsan dan Indra Surya. 2004. "Aspek Hukum Pasar Modal Indonesia”, Jakarta: Prenada Media.

Nazir, Moch, "Metode Penelitan", Cetakan Kelima, Ghalia Indonesia, Jakarta, 2003

Novitasari, Bunga "Pengaruh Profitabilitas, Pertumbuhan Penjualan dan Kebijakan Deviden Terhadap Harga Saham ( Per 2011-2013)", Jurnal IImu dan Riset Akuntansi Vol. 4, No 2 STIESIA Surabaya, 2015

Nur Aini, "Pengaruh CAR, NIM, LDR, NPL, BOPO Dan Kualitas Aktiva Produktif Terhadap Perubahan Laba (Studi Empiris pada Perbankan di BEI tahun 2009-2011)", Jurnal Dinamika Akuntansi, Keuangan dan Perbankan, Vol. 2, No. 1 Hal. 1425,Univ. Stikubank Semarang, 2013

Pratiwi Lisma, "Analisis Faktor-Faktor yang Current Asset debt Equity Ratio dan Return On Equity mempengaruhi Harga Saham pada Perbankan Syariah di Indonesia (Per 2003-2013)", 2013

Rianto, Bambang "Dasar-dasar Pembelanjaan Perusahaan, Edisi Ke Empat, BPFE Yogyakarta 2001

Rinati Ina, "Pengaruh Net Profit Margin Return On Asset dan Return On Equity Terhadap Harga Saham yang tercantum dalam Indeks LQ45 (Per 2004-2008) Universitas Gunadarma, 2014

Satrio wibowo, Edhi dan Muhammad Syaichu, "Analisis pengaruh Suku Bunga, Inflasi, CAR, BOPO, NPF terhadap Profitabilitas Bank Syariah", Jurnal of Management, Vol. 2, No. 2 Hal 1-10 Univ. Diponegoro, 2013

Shain, Uma, "Manajemen Dasar Edisi Ke 4 buku ke 2", Salemba Empat, Jakarta, 2008

Siamat, Dahlan, "Manajemen Lembaga Keuangan, Edisi Kelima, Fakultas Ekonomi Universitas Indonesia, Jakarta, 2005

Sudana, I Made, "Manajemen Keuangan Perusahaan Teori dan Praktek", Erlangga, Jakarta, 2011

Sudha Adnyana, Candra dan Ketut Alit Suardana, "Pengaruh BOPO, pertumbuhan Asset dan NPF terhadap ROA", E-Jurnal Akuntansi, Hal 1616-1641, Univ. Udayana Bali2016

Sugiyono, “Metode Penelitian Kuantitatif dan Kualitatif", Alfabeta, Bandung 2013 
Sugiyono. 2014. Metode Penelitian Pendidikan Pendekatan Kuantitatif, Kualitatif Dan $R \& D$. Bandung: Alfabeta.

Sukirno, Sadono, "Pengantar Teori Ekonomi Makro", Raja Grafindo Persada, Jakarta, 2004

Sunardi, N. (2019, January). Relevansi Struktur Kepemilikan Tentang Profitabilitas Dan Nilai Perusahaan (Studi pada Industri Manufaktur yang Terdaftar di Bursa Efek Indonesia Periode 2010-2017). In PROCEEDINGS (Vol. 1, No. 1).

Sunardi, N., \& Sasmita, A. S. (2019). Pengaruh Likuiditas, Leverage Dan Growth Terhadap Kinerja Industri Makanan Dan Minuman Yang Tercatat Di Indonesia Stock Exchange Selama Periode Tahun 2011-2015. Jurnal Sekuritas (Saham, Ekonomi, Keuangan dan Investasi), 2(2), 81-97.

Surat Edaran BI No. 9/24/DPbS tahun 2007, "Tentang Kriteria Penilaian Non Performing Financing", 2007

Sutrisno, "Manajemen Keuangan (Teori, Konsep, dan Aplikasi)", Edisi Pertama, Cetakan kedua, Ekonisia, Yogyakarta, 2003

Syofian, Siregar, "Metode Penelitian Kuantitatif", Prenada Media Group, Jakarta, 2013

Van Horne, James C, "Fundamentalis of Financial Management", Tenth Edition, Prentoce Hall International, New Jearsey, 1998

Weston, J. Feed dan Thomas E. Copeland. 2009. Manajemen Keuangan. Jakarta: Binarupa Aksara

Winarno, Wing Wahyu, "Analisis Ekonometrika dan Statistika dengan Eviews", YKPN, Yogyakarta, 2002

Yasir, Muhammad dan W. S Mahriana, "Faktor-Faktor Yang Mempengaruhi Tingkat Profitabilitas Bank Pembiayaan Rakyat Syariah (BPRS) Di Aceh", Jurnal lqtishadia, Vol. 9, No. 2, UIN Ar Raniry Banda Aceh, 2016 